\title{
Scenario-Based Actions to Upgrade Small-Scale Furniture Producers and their Impacts on Women in Central Java, Indonesia
}

Author(s) :H. Purnomo, R.H. Irawati, A.U. Fauzan and M. Melati

Source: International Forestry Review, 13(2):152-162. 2011.

Published By: Commonwealth Forestry Association

URL: http://www.bioone.org/doi/full/10.1505/146554811797406660

BioOne (www.bioone.org) is a nonprofit, online aggregation of core research in the biological, ecological, and environmental sciences. BioOne provides a sustainable online platform for over 170 journals and books published by nonprofit societies, associations, museums, institutions, and presses.

Your use of this PDF, the BioOne Web site, and all posted and associated content indicates your acceptance of BioOne's Terms of Use, available at www.bioone.org/page/terms_of_use.

Usage of BioOne content is strictly limited to personal, educational, and non-commercial use. Commercial inquiries or rights and permissions requests should be directed to the individual publisher as copyright holder. 


\title{
Scenario-based actions to upgrade small-scale furniture producers and their impacts on women in Central Java, Indonesia
}

\author{
H. PURNOMO ${ }^{1,2}$, R.H. IRAWATI ${ }^{1}$, A.U. FAUZAN ${ }^{3}$ and M. MELATI ${ }^{4}$ \\ ${ }^{1}$ Center for International Forestry Research (CIFOR), Bogor 16000, Indonesia \\ ${ }^{2}$ Bogor Agricultural University, Jl. Raya Darmaga, Kampus IPB Darmaga, Bogor 16680, Indonesia \\ ${ }^{3}$ Independent consultant living in Jakarta, Indonesia \\ ${ }^{4}$ Student from the Australian National University, Canberra, Australia \\ Email: h.purnomo@cgiar.org and r.irawati@cgiar.org
}

\begin{abstract}
SUMMARY
Indonesian furniture accounts for almost $1 \%$ of the global furniture trade, valued at more than USD 135 billion. In many countries, including Japan, European countries and Indonesia, women make decisions about selecting which furniture to buy. In Central Java's Jepara District - the centre of teak furniture production in Indonesia - annual furniture exports are valued at USD 120 million. However, the roles of small-scale producers and women workers in furniture industry are weak. Though women workers play an important role in generating revenue, they are paid less than men. They are also less powerful and exercise less control over resources, decision making, product development and bargaining. Action research and value chain analysis were used to improve small-scale producers and women workers. This paper explores different scenarios for upgrading small-scale producers, such as participation in trade exhibitions, training programmes and producer associations and their effects on women workers.
\end{abstract}

Keywords: furniture, Central Java, gender, value chain analysis, scenario

Actions basées sur des scénarios visant à élever les petits producteurs de mobilier et leur impact sur les femmes dans le centre de Java, en Indonésie

H. PURNOMO, R.H. IRAWATI, A.U. FAUZAN et A. MELATI

Le mobilier indonésien forme presque $1 \%$ du commerce global de meubles, qui est évalué à plus de 135 milliards de \$ US. Dans plusieurs pays, comme le Japon, les pays européens et l' indonésie, ce sont les femmes qui décident quel meuble sélectionner et acheter. En contrepartie, le rôle des femmes travaillant dans l'industrie du mobilier n'a jamais été clairement identifié. Dans le district du Jepara, au centre de Java, centre du mobilier indonésien à base de teck, les exportations annuelles de mobilier sont évaluées à 150 millions de \$ US. Une recherche active et une analyse de chaîne de valeurs ont été utilisées pour prouver le rôle et la positon des travailleurs de sexe féminin. Bien que les femmes ouvrières soient importantes dans la part des revenus crées, elles sont payées $50 \%$ de moins que les hommes. Elles on également moins d'influence et ont moins de contrôle sur les ressources, la prise de décision, le développement des produits et le marchandage. Différents scénarios pour aider une promotion des petits producteurs, l'établissement de programmes de formation et d'associations de producteurs et leur effet sur le rôle des femmes ont été explorés plus profondément.

Investigación-acción basada en escenarios para la mejora del rol de los productores de muebles de pequeña escala y su impacto en las trabajadoras de Java Central, Indonesia

H. PURNOMO, R.H. IRAWATI, A.U. FAUZAN y A. MELATI

Los muebles de Indonesia representan casi el 1\% del comercio global de muebles de madera, valorado en más de 135000 millones USD. En muchos países, incluyendo a Japón, los países europeos e Indonesia, las mujeres toman decisiones a la hora de elegir qué muebles comprar. Sin embargo, aun no se ha identificado claramente el papel de las trabajadoras de la industria del mueble. En el distrito de Jepara en Java Central, centro por excelencia del mueble indonesio realizado en teca, las exportaciones anuales de muebles se valoran en 150 millones USD. Se utilizaron la investigación-acción y el análisis de la cadena de valor para demostrar el rol y el estatus de las trabajadoras. Aunque las trabajadoras son importantes a la hora de generar ingresos, se les paga un 50\% menos que a los hombres. Gozan asimismo de menor autoridad y ejercen un menor control sobre los recursos, la toma de decisiones, el desarrollo de productos y la negociación. Se exploraron en mayor profundidad diferentes escenarios para la mejora de productores de pequeña escala tales como la participación en ferias y exposiciones comerciales, programas de capacitación y asociaciones de productores y su efecto en el rol de la mujer. 


\section{INTRODUCTION}

Furniture making is the most labour-intensive industry in forestry. In 2009, the global furniture trade accounted for USD 135 billion $^{1}$, or approximately $1 \%$ of all world trade in manufactured goods. Furniture is a big business involving a large number of workers. Small and medium enterprises (SMEs) have such an important role in the furniture sector that any decrease in trading volume will increase poverty. Conversely, furniture industry growth will increase the number of jobs available, and likely reduce unemployment. Increasing added value in the domestic part of the industry's value chain would improve the quality of jobs and provide more decision making and participation to workers and smallscale employers. Surveys found there was decline of $20 \%$ of furniture producers in last five years (FVC 2011). International Labor Organization (ILO) highlights the urgency to maintain labor employment and improve livelihood in labor intensive industry such as furniture (Herr et al. 2006). Women are larger part of furniture workers particularly in finishing processes like sanding and furnishing (Ewasechko 2005). There is a need for improving livelihood of small-scale producers and women role in furniture industry due to the declining situation. However, upgrading small-scale producers and improving women' role are not trivial. The interdependency between large and small-scale producers as well as men and women make the situation is complex.

While the amount of added value in total is very high, its distribution is imbalanced. Purnomo (2009) demonstrates that overseas stakeholders added significantly more value than domestic stakeholders did in the production and trade of furniture for export. Furthermore, finishing and exporting companies take a greater portion of the added value than small-scale furniture producers and tree growers do. Both men and women are involved at all nodes along the furniture value chain. The furniture value chain has also seen rising levels of female employment. However, the role of women in the industry has yet to be clearly identified, and though women workers are important in generating revenue, they are paid less than men who work the same hours. They are also less powerful, exercising less control over resources, decision making, product determination and bargaining. This gender gap in earnings and the lack of women's voices in decision making at various stages of the value chain is happening all over the world, from Sub-Saharan Africa, South Asia and Southeast Africa to Latin America both in agricultural and non-agricultural fields (Fontana 2010).

In buyer-driven value chains, gender plays a significant role in both production and retail, as examples from the furniture industry in this study show. Many factories employ large numbers of women workers. They have taken advantage of existing gender relations to furnish a labour force capable of producing high quality products cheaply for export. In this study, we focused on the role of women in furniture value chain governance and the impact of interventions to upgrade the value chain. Upgrading the furniture value chain is necessary to improve the livelihoods of small-scale producers and sustain the furniture industry. Upgrading means that a multidimensional process that aims at increasing the economic competitiveness of enterprises, as well as having a positive impact on social development (Herr et al. 2006). However, it does not necessarily improve the role of women working within it. Literature on value chain assessments provide many examples of this situation. A fisheries value chain evaluation study in Vietnam found that modernisation of its fishing ports was likely to reduce the demand for labour and remove the economic niches in fish marketing and processing that poor women occupy (ADB 2001). Fajardo et al. (2006) as cited in Risgaard et al. (2011) found that one project, funded by the Swedish development agency, on upgrading coffee and domestic livestock in Nicaragua did not include women in training and upgrading. Miller and Amato (2007) found that another project, funded by the US development agency, on strengthening porcine, pond and aquaculture value chains in Cambodia impacted negatively upon gender equality; the female-run businesses lacked mobility, which was the key factor for business success. However, Agarwal (2010) found in cases in India that women cooperate more in mixed groups than in all-female groups.

This paper describes action research, which aims to improve the relationship between women and men in the context of the furniture industry. The paper specifically answers three questions we posed in our research: 1) What roles do women have in different furniture value chain governance types? 2) How do specific interventions, such as trade exhibitions, training activities and setting up producer associations affect women's participation in the chains? And 3) How can the industry make value chain governance more open to women? Although this study was carried out in a specific district in Central Java, its findings can be used in other parts of the world in situations where culturally rooted industries' women workers are marginalised.

\section{CONTEXT AND METHODOLOGY}

\section{Furniture in Jepara}

About $90 \%$ percent of the furniture industry in Indonesia is composed of small and medium enterprises (SMEs). In Jepara District, Central Java, the furniture industry contributes about $27 \%$ of the district's economy. Exports were valued at about USD 120 million in 2009. The government, however, has categorised the furniture sector as an industry in decline. The SMEs have a lower market position than the bigger players. Still, the livelihoods of millions of people along the value chain depend on the sustainability of the furniture industry (Ewasechko 2005).

A survey conducted in 2005 estimated that 15,271 furniture enterprises existed in Jepara (Roda et al. 2007). In five

\footnotetext{
1 All currency figures are in US dollars unless otherwise indicated.
} 
years, the furniture market has changed substantially. A survey in 2010 found only 11,597 independent enterprises and 384 integrated enterprises. Independent enterprises, such as workshops or sawmills, focus on specific activities, while integrated enterprises are business units that integrate two or more activities, a workshop and showroom, or a log pond and sawmill, for instance (see Table 1). The number of furniture enterprises fell by $20 \%$ in the five-year period from 2005 to 2010 (FVC 2011). The distribution of furniture enterprises in Jepara and gender dominance are shown in Figure 1.

In Jepara, $98 \%$ of furniture workshops are classified as small-scale businesses $1.9 \%$ are medium-scale and $0.1 \%$ are large-scale. The Jepara furniture industry uses mostly teak and mahogany. Most workshops $(89.5 \%)$ produce indoor furniture, while $7.8 \%$ produce outdoor furniture. The remaining workshops produce carvings, handicrafts and calligraphy (FVC 2011).

The use of teak in furniture making has long been a part of Javanese culture. Centuries of historical records dating back to the seventh century BCE describe the abundance of teak forests in Central Java and the formation of skilled carpentry groups. The Javanese consider teak and items made from teak a valuable part of their culture, a species apart from other types of wood. Local carvers and furniture makers absorbed the influences of Chinese, Indian, Arabic and European designers, producing to this day intricate designs and highly sought after furniture. The 17 th century port city of Jepara, once a bustling centre of maritime commerce, remains today

TABLE 1 Furniture enterprise types in Jepara (after FVC 2011)

\begin{tabular}{lrl}
\hline Type of business & Number & Dominance \\
\hline Independent enterprises & & \\
\hline Log pond & 726 & Male \\
\hline Sawmill & 101 & Male \\
\hline Dry kiln & 20 & Male \\
\hline Workshop & 8080 & Balanced \\
\hline Ironmongery & 168 & Balanced \\
\hline Warehouse & 528 & Female \\
\hline Showroom & 1974 & Female \\
\hline Subtotal & 11,597 & \\
\hline Integrated enterprises & & \\
\hline Log pond and sawmill & 137 & Male \\
\hline Workshop and showroom & 78 & Female \\
\hline Workshop and dry kiln & 71 & Male \\
\hline Workshop and log pond & 37 & Male \\
\hline Workshop and warehouse & 15 & Female \\
\hline Other integrated business & 46 & Balanced \\
unit & & \\
\hline Subtotal & 2384 & \\
\hline Total & & \\
\hline & & \\
\hline
\end{tabular}

a major centre of furniture production in Central Java (Purnomo et al. 2009).

Business relations between furniture producers and their buyers are usually imbalanced: Buyers set prices and producers cannot negotiate better deals. These unfair relations are part of the legacy from Javanese court practices. Patron-client relationships among members of the Javanese royal household and their subservient carpenters have defined that imbalance since the seventh century when Queen Shima instructed her skilled workers to create specific furniture and art designs for her palace with no compensation. In 1700, Queen Kalinyamat encouraged her woodworkers to produce high quality furniture for international trade, as did the Indonesian heroine, Kartini in 1800, who helped promote their work to Europeans with whom she corresponded. Patrons supported woodworkers by instructing product designs, opening access to markets, and ensuring steady orders. Their role was often considered 'godly', highly honoured and never questioned. These patron-client relationships are still present in modern day relations between buyers and Indonesian furniture producers (Purnomo et al. 2009). Although the relationship was imbalanced, Queen Shima and Queen Kalinyamat were very powerful women who ran their kingdoms. Women were very powerful at that time.

\section{Methodology}

In defining 'gender' our study understands it to be a social construct of the differences between women and men, not a matter of sex (Kabeer 1999). Gender is about how society gives meaning to differences in femininity and masculinity, and the power relations and dynamics that result (Laven et al. 2009 in Riisgaard et al. 2010). A gender role is defined as a set of perceived behavioural norms associated particularly with males or females, in a given social group or system. It can be in the form of division of labour by gender (Peter 2006). Gender relations are also defined as the social construction of roles and relationships between men and women in a community or system (Baden et al. 1998 as cited in Risgaard et al. 2011).

We used secondary data collection, value chain analysis (VCA) and action research to understand the role and position of women workers in Jepara's teak value chain, and their struggle to earn more for their labour and move into more specialised and higher paying jobs within the industry.

Kaplinsky and Morris (2001) characterise market-based governance as having many customers and suppliers, where repeat transactions are possible, but information flows are limited, and no technical assistance occurs. In a balanced network, a supplier has many customers, much information flows in both directions, and both sides regularly solve problems through negotiation. In a directed network, a primary customer takes at least $50 \%$ of a manufacturer's output, the customer defines the product and provides technical assistance; and information flows are imbalanced. Hierarchical governance is characterised by vertical integration, customers owning supplying businesses, and manufacturers having limited autonomy to make independent decisions. 
FIGURE 1 Furniture business unit distribution in Jepara (inset Indonesia)

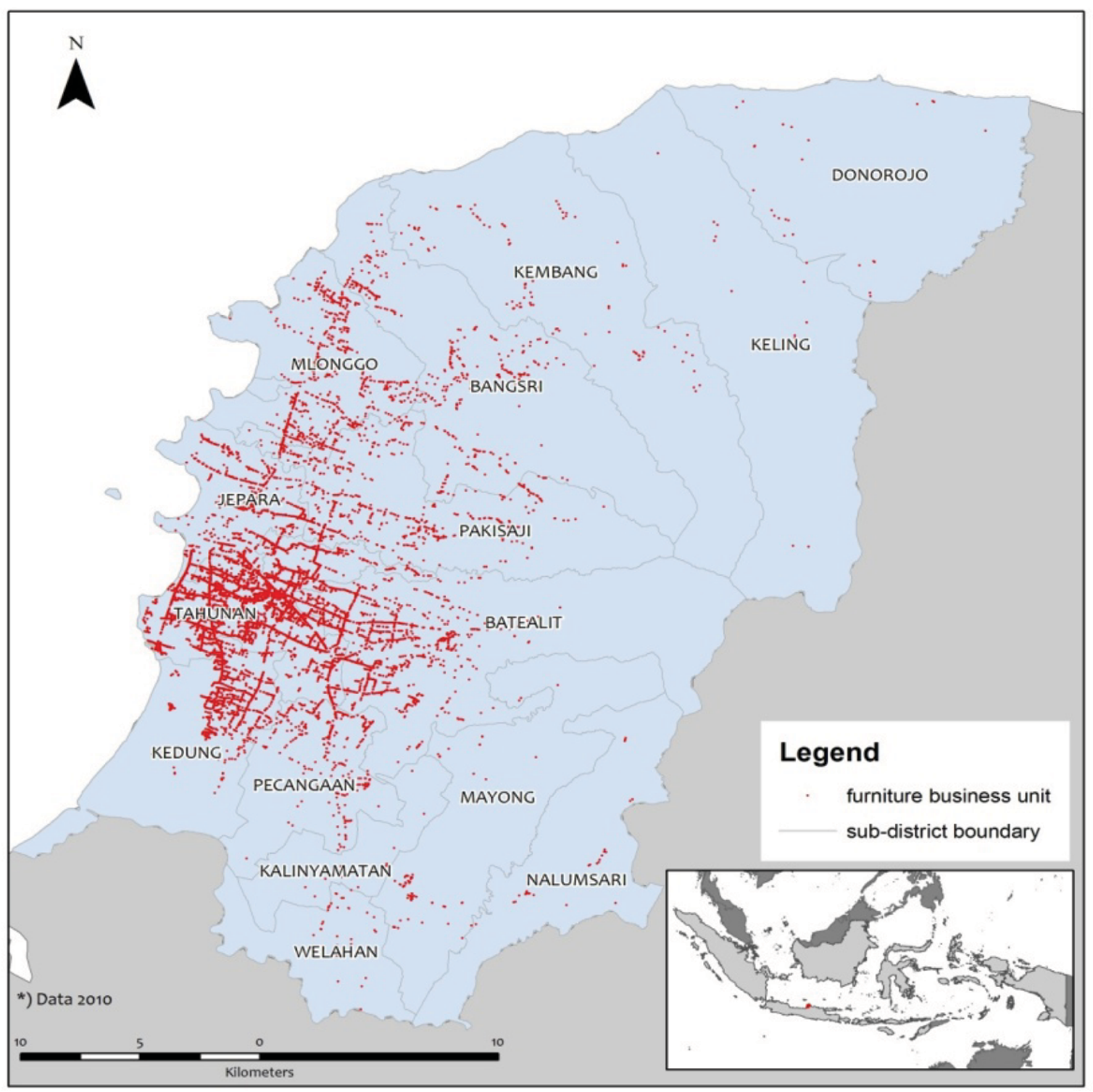

Action research (AR) is a process through which members of a community identify a problem, collect and analyse information, and act upon the problem to find solutions and to promote social and political transformation with support from an external facilitator (Selener 1997). We, as researchers and facilitators, collaborated with community members or stakeholders and perceived them as co-researchers in the AR. Action research uses a cycle of reflection, planning, action and monitoring (see Figure 2). McIntosh (2010) emphasises the creativity of reflection in AR processes.

During the reflection phase, researchers established communications through field visits to identify stakeholders and study furniture value chains. We identified the stakeholders and the gaps and problems they face. Value chain analysis has emerged as a novel approach for understanding how power, benefits and costs are embodied and distributed to various actors, men and women. (Kaplinksi and Morris 2001).

During the planning phase, stakeholders developed scenarios for resolving the problems they identified. Planning took place in a participatory manner, guided by recommendations from the reflection phase. During the action phase stakeholders prioritised and executed the planning in a participatory manner with the aim of creating a balanced value chain. Local stakeholders devised a set of indicators, 
FIGURE 2 The reflection-planning-action-monitoring loop used for upgrading

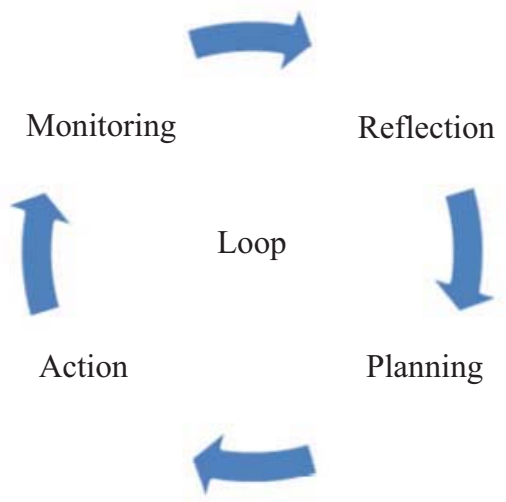

which was used in the monitoring phase to evaluate implementation of the plans.

Furniture producers, where women workers are located, are involved in relationships with other actors to deliver their products to consumers. Four scenarios were developed for improving the role of small-scale furniture producers: moving up, organising SME associations, collaborating down and developing green products. These scenarios were developed into action plans, and implemented to strengthen the role of small-scale producers. The impacts of these scenario-based interventions on women workers were scrutinised. Twelve people - eight women and four men - participated in focus group discussions to assess how the scenario-based actions (organising an SME association, moving up, collaborating down and creating green products) proposed in the value chain studies affected women's roles in the furniture value chain. First, participants explored what type of value chain governance women were most comfortable with. Second, participants were questioned whether the action taken impacted and potentially impacted women, also discussed possible scenarios for empowering more women. During the discussion we supported women to express their ideas freely and allocated more time to women to speak up.

\section{RESULTS}

\section{Furniture value chain governance and gender roles}

Our value chain analysis, as the reflection phase of action research, focused on governance mechanisms in the chain, as governance would ultimately determine which intervention strategies stakeholders would choose. Four types of value chain governance were found in Jepara: market-based, balanced network, directed network and hierarchical.

The value chain in Jepara exhibits four governance types at different parts of the chains (see Figure 3). The governance type among finishing companies that also act as exporters and importers/global brokers is a directed network. However, when the import companies and finishing companies are owned by a single owner, the governance type becomes hierarchical. The finishing companies receive instructions from global buyers about specifications and design. The global buyers are subsidiaries of overseas retailers. Very few finishing companies develop their own designs. These enterprises were protective of their business information and careful not to risk others imitating their designs for mass production. Some finishing companies own showrooms in Jepara and other cities. However, exporters were driven by importers and global brokers, which were in directed network relationships with international retailers.

Small-scale producers are in a directed network relationship with domestic brokers. The brokers have become the small-scale producers' main customers and take more than $50 \%$ of their products. The brokers can easily shift from one producer to another. This condition has resulted in a directed network type of governance between exporters and smallscale producers. In some situations, the relationship has become hierarchical when exporters exercise more control over small-scale producers who are hired directly by exporters. Few small-scale producers have their own showrooms. Mechanised furniture producers have a better position in the value chain. They are in a balanced network with the next enterprises along the value chain; global brokers and importers.

The relationships between small-scale producers on one side and sawmill owners and wood retailers on the other are market-based. They are connected based on market principles, since there are many of them. No single enterprise controls transaction or price. Small-scale producers can freely buy wood from retailers. When they have enough money they often seek retailers from all over Java. However, if they have less money, they tend to acquire wood on credit from nearby retailers. They are also free to choose which sawmill will saw their logs.

Wood retailers and tree growers operate in a directed network. Perhutani, the state-owned plantation forest company, has more control and power than wood retailers have, and consequently determines pricing and quality. With about 1 million hectares of teak plantations, Perhutani is a large teak grower and dominates its position in the value chain. Community-based agroforestry, which is small in scale, is less powerful than wood retailers, who control the forest farmers participating in community-based agroforestry.

Both men and women are involved in all six furniture value nodes including furniture retailers, finishing companies and exporters (furniture warehouses), small-scale furniture workshops, sawmills, wood retailers and forest plantations. However, women are more concentrated in warehouses than anywhere else along the value chain. In the warehouses women sand, hand paint and hand varnish furniture pieces rarely using spray guns - and wrap them for shipping. In the furniture workshops women also carve and source furniture materials, mainly by telephone. Women are also involved in bookkeeping and record keeping, managing cash payments and customer relations and overseeing the quality of finished products. Men's work along these six nodes is distinct from that of women. They design furniture, source furniture materials by travelling around, lift logs and pieces of furniture, 
FIGURE 3 Value chain governance involving small-scale producers in Jepara

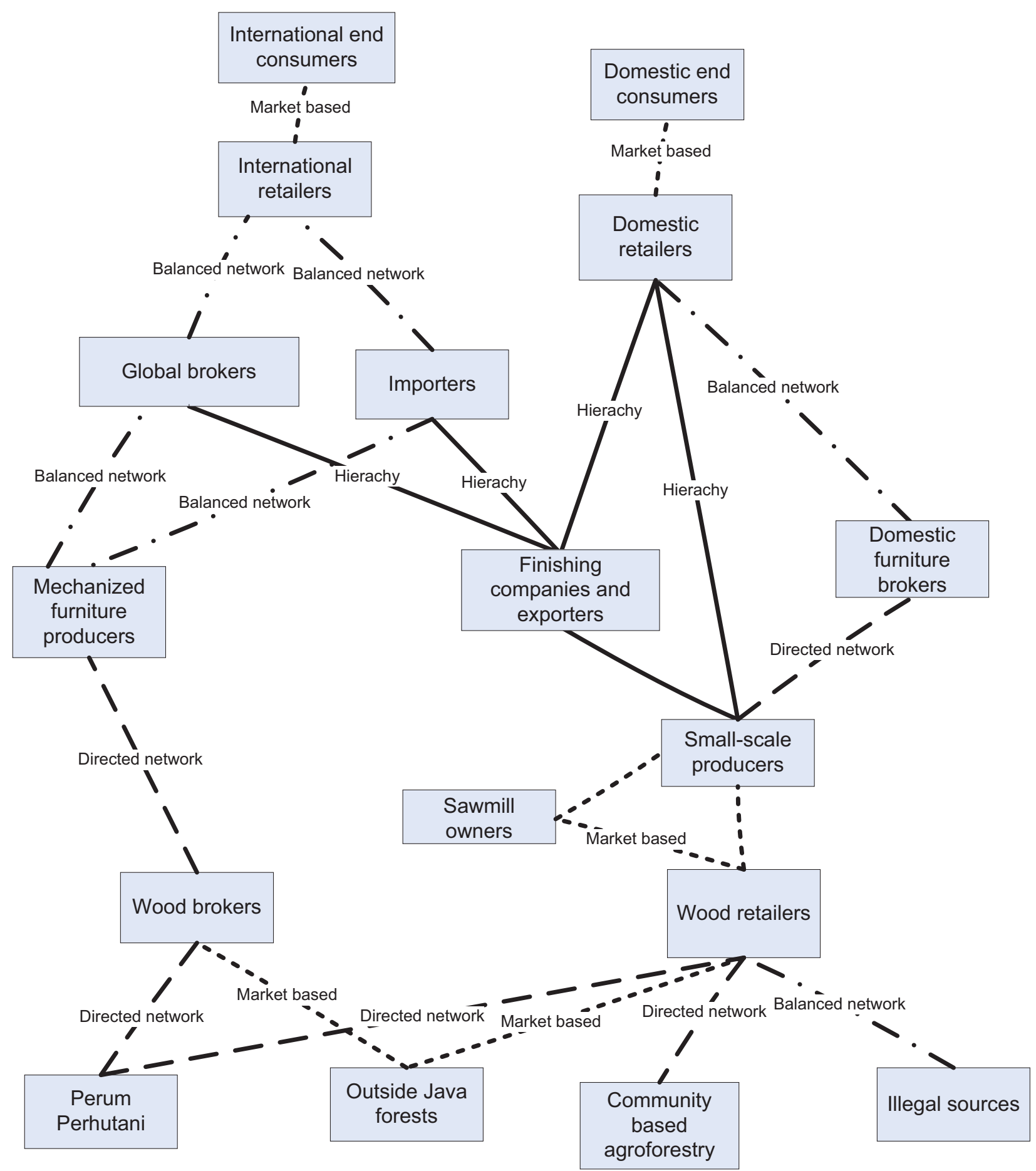

mill timber, maintain sawmill equipment, do carpentry, carve and pack heavy articles. Men also sand with sanding machines, repair cracks and apply spray finishes. Some activities usually carried out by men are sometimes done by women, for example marketing, pricing, making furniture catalogues and deciding where to re-invest profits (Nansereko 2010).

Although both men and women are active in the furniture value chain, men make more decisions and work in better paying jobs. Women are perceived to lack furniture-making skills, and are also perceived to be risk averse. Some work, for instance operating complex machinery, is considered too risky for women. Another reason is the cultural division of labour; men make money while women tend the home, cook food and educate children (Nansereko 2010). Consequently, men's voices are heard much more than women's are.

In the mixed-gender focus group discussions, all women said their roles in the value chain were strong, but only some of the men agreed. From 12 participants, seven of eight women thought their role was strong, and one woman thought 
their role was very strong. Two of four men perceived the role of women as medium, and the other two male participants perceived it as strong.

Female participants said that although physically women are weaker than men are, in fact women work at different nodes in the chain than men do. In certain nodes, including finishing, participants said women can do a better job than men. Other comments included, 'women can do anything,' and 'women, although they should be responsible for working at home, could work in many parts of the furniture business.' Male participants also said women's role in the value chain is quite strong as they have a role at each node, and added that women also function as motivators and are good team leaders.

Table 2 shows participants' scoring of the strength of women's roles by governance type. The figures represent the number of participant votes. Two participants did not answer, so the scores only reflect the views of 10 participants. Women were perceived to have a stronger role in market-based relationships with the highest median score, and the weakest role in the hierarchical relationships. The balanced and directed network scores were in between. Participants also said marketbased relationships provide better profit opportunities for furniture companies, and more freedom and lack of restrictions for women. By freedom they meant women have more space to arrange their time and take care of their families. They said that hierarchical and directed network value chain types result in less risk for women. They liked the marketbased value chain type, but did not like the market risk.

\section{Scenario-based actions}

Small-scale furniture producers have established the Small-Scale Furniture Producers Association (APKJ) in
Jepara District. The association's vision is to improve smallscale furniture producers' potential to make them more independent and competitive in the global market, and to empower APKJ members for the prosperity and advancement of the Jepara furniture industry. Its mission is to improve small-scale furniture producers' bargaining skills, create fair market prices and facilitate access to credit.

Table 3 lists actions in the agreed scenarios. In all these scenarios, we did not distinguish between men and women, and perceived and treated them equally.

The association facilitates collective action and is recognised by the Jepara District Government, which involves it decision-making processes. An indication of this recognition has been the Jepara District Government inviting APKJ to many of its important meetings and exhibitions. Small-scale producers have used this association to channel their voices in decision-making processes and balance their power vis-à-vis large companies.

In the moving up scenario, producers would change position within the chain. This scenario encourages small-scale producers to move up to the higher stages in the value chain, to also function as furniture brokers, finishing companies and exporters. To realise this scenario, APKJ has held exhibitions in Jepara, Jakarta and Bogor to develop ties with potential buyers. APKJ practiced selling and attracting buyers interested in business contracts. Some buyers have since visited Jepara for further negotiations. The association has also developed collective marketing through the Internet at http:// www.javamebel.com. Small-scale producers have used this portal to market their products.

Participating in international exhibitions is part of the annual programme of the Jepara APKJ. With support from CIFOR and the Indonesian Ministry of Forestry's Forestry

TABLE 2 Strength of women's roles in value chain types

\begin{tabular}{lcccccc}
\hline \multirow{2}{*}{ Type } & \multicolumn{5}{c}{ Most frequent score } \\
\cline { 2 - 7 } & Very weak & Weak & Medium & Strong & Very strong & Most frequent score \\
\hline Market based & 0 & 1 & 0 & 9 & 0 & strong \\
\hline Balanced network & 0 & 0 & 5 & 5 & 0 & medium to strong \\
\hline Directed network & 0 & 0 & 3 & 6 & 1 & strong \\
\hline Hierarchical & 0 & 0 & 5 & 2 & 3 & medium \\
\hline
\end{tabular}

TABLE 3 Selected actions for each scenario

\begin{tabular}{ll}
\hline Scenario & \\
\hline SME association & - Establishment of Jepara Small-scale Producers Association (APKJ) \\
& - Management training \\
\hline Moving up & - Participation in trade exhibitions in Jakarta and Jepara \\
& - Workshops e.g. CHAFTA (China-ASEAN Free Trade Agreement), structure of furniture industry \\
& - Training - marketing, quality control and finance \\
\hline Collaborating down & - Negotiation with farmers to plant trees \\
\hline Green products & - Participation in tree planting \\
\hline
\end{tabular}


Research and Development Agency (FORDA), it managed two booths at an Export Products Exhibition at the Jakarta International Expo in Kemayoran, Jakarta, on 13-18 October 2010. APKJ association members gained practical experience interacting directly with international buyers. Both booths attracted many visitors, particularly during the first three days of the expo. The outdoor furniture booth took in more enquiries than the indoor furniture booth. At the outdoor furniture booth, foreign buyers asked practical questions about production capacity and tendering. The booths attracted around 500 visitors, and APKJ collected some 100 names and contact details.

APKJ members gained additional experience from the international exhibition because they observed other exhibitors' booth set-ups and client rapport. APKJ used the opportunity to promote its online store, javamebel.com. The expo showcased many wood products and other items combining wood with iron, aluminium, rattan and synthetics. Some booth visitors asked about prospective suppliers for their companies. Other visitors proposed cooperation or collaboration.

In the collaborating down scenario, small-scale producers would collaborate with wood traders and tree growers. Awareness has been raised and a preliminary study conducted to develop partnerships between furniture producers and forest farmers. APKJ negotiated with tree farmers to plant teak in their neighbourhood, and was involved in planting trees with a student nature lovers' association to green Jepara.

In the green product scenario, various companies along the value chain would produce and sell eco-labelled furniture from certified timber, relying on coordination up and down the chain. Certification training for small-scale producers was conducted in collaboration with the Indonesian Ministry of Trade on 27-29 July 2010. This vision to produce certified furniture has been disseminated among small-scale producers. Thirty APKJ members participated in the training. They learned new ways of thinking about certified timber that they could share with their colleagues and other association members.

\section{Assessment of impacts on women}

The focus group participants were asked about their perceptions of the impacts (Table 4) and potential impacts (Table 5) of each scenario on women. Most participants believed that all scenarios provided favourable impacts for women, although the moving up scenario would affect women more than the other scenarios. This means that having closer ties to furniture buyers would benefit women as well as men, due to the fact that women prefer the market-based value chain scenario. The other three scenarios received similar scores, showing a medium impact on women.

Participants also were asked which scenarios could create better impacts in the future. All scenarios, including SME association, collaborating down, and green products could potentially bring about strong impacts for women if they were better implemented. For instance, having a specific forum for women only under the SME association scenario is likely to produce stronger impact. Participants proposed that an arisan could constitute such a forum. An arisan is a popular social activity among women in Indonesia. Arisan members put money in a collective pot on a regular basis, every month or week. The group holds a draw and the winner takes the pot. Arisan is an effective way for women to meet regularly, and women were found to cooperate more effectively in an all-female group than as the minority in a mixed group.

Training and skills workshops designed specifically for women on product quality management, financial management, marketing, information technology and finishing will boost the likely impact of the moving up scenario. However, this does not mean that its implementation so far has failed to offer improvements for women. Rather, the participants described ways to improve future impact.

TABLE 4 Impacts of actions in each scenario on women

\begin{tabular}{lcccccc}
\hline \multirow{2}{*}{ Scenario } & \multicolumn{7}{c}{ Favourable impact } \\
\cline { 2 - 8 } & Very low & Low & Medium & Strong & Very strong & Score Mode \\
\hline Moving up & 0 & 1 & 2 & 6 & 1 & strong \\
\hline SME association & 0 & 1 & 7 & 2 & 0 & medium \\
\hline Collaborating down & 0 & 1 & 7 & 2 & 0 & medium \\
\hline Green product & 0 & 1 & 6 & 3 & medium \\
\hline
\end{tabular}

TABLE 5 Potential impacts of actions in each scenario on women's roles

\begin{tabular}{lcccccc}
\hline \multirow{2}{*}{ Scenario } & \multicolumn{5}{c}{ Potential impact } \\
\cline { 2 - 7 } & Very low & Low & Medium & Strong & Very strong & Score Mode \\
\hline Moving up & 0 & 0 & 2 & 6 & 2 & Strong \\
\hline SME association & 0 & 0 & 3 & 7 & 0 & Strong \\
\hline Collaborating down & 1 & 0 & 1 & 8 & 1 & Strong \\
\hline Green product & 1 & 0 & 3 & 4 & Strong \\
\hline
\end{tabular}




\section{DISCUSSION}

Gender analysis is essential to a comprehensive value chain analysis. In the furniture value chain studied, with rising levels of female employment, both men and women are actively involved in activities along the chain. Gender is thus an integral element in how each of these activities is performed, and their interconnections from furniture conception and design through to the final stage of retail purchase.

Governance is another critical area of value chains analysis (Muradian and Pelupessy 2005). Much of the focus is on the power of companies at different nodes of the value chain to control or govern upgrading activities, and the terms on which different firms participate within the chain. Women normally occupy a subordinate position relative to men within power relations. If governance is linked to the power of one company over another, it might also be linked to women's concentration in particular types of company relative to others within the value chain. Governance in value chains takes place not only between companies, but also within them. The power to govern upgrading activities in a context in which women occupy a subordinate position in the gender hierarchy within the company can facilitate the enhancement of economics.

Women participants said they preferred a market-based value chain because in it they earn more money. However, at the same time they worry about market uncertainties. These are general economic concerns about trade-offs between risk and earning power.

We conducted all phases of the action research in a participatory manner, but we did not differentiate between female and male participants. In implementing the four scenarios, we did not avoid men-dominated activities. Men dominate the furniture industry and people perceived this dominance as natural. There is a 'social acceptance' of women as flexible workers because of their ties to the household, carrying the burden of multiple roles. As researchers, we did not pay specific attention to women. In other words, we followed existing norms. This research checked whether our non-gender sensitive scenario-based actions would impact negatively upon women.

For instance, the Small-scale Furniture Producers Association (APKJ) established in Jepara was not specifically aimed at men or women; it was set up as a gender-neutral organisation. Once the APKJ board realised the differences of women's roles in these businesses, they tried to involve women in their activities. However, some restrictions still apply to women who do participate. The norms in Jepara discourage women from going out on their own at night and women are often uncomfortable attending predominantly male meetings.

According to Risgaard (2010), findings in Vietnam and Cambodia suggest that by paying specific attention to women workers in the value chain they can experience positive impacts. Training and capacity building activities, for instance, are commonly targeted at men, who have access to new knowledge and skills. When men are targeted, they tend to accumulate more knowledge and skills, while women, who participate more passively, tend to accumulate less. Ultimately, the gap between men and women often widens after such interventions.

In Jepara, we did not target the interventions specifically at men or women, but despite the generic interventions being dominated by men, they had strong positive impacts on both men and women. We did not find that generic interventions widened the gap between men and women. Women did not complain of being marginalised by the absence of specific women-only activities during the action research.

These results can be explained by the context of home industries in Jepara. In every small-scale enterprise, men and women work closely together and working arrangements reflect family structure. The father can act as the head of the enterprise, the mother as treasurer and secretary and their children make up the primary labour force. If necessary the enterprise will hire other workers, but the structure will remain familial. Since the enterprise is basically a household the information flow among household members is high. This explains why knowledge and skills obtained by the father are easily distributed to women in family businesses.

Few firms are headed by women, who participated in our action research activities, but did not take a leading role in any actions. The gender imbalanced norms are still attributed mostly to women. They have limited access to many economic activities because women are more responsible for household tasks, such as caring for children, preparing family meals and tending the home, termed reproductive (unpaid) work. Men, on the other hand, are responsible for earning money, being the main breadwinner for the family, termed productive work. In this case, the furniture value chain in Jepara reflects the socially derived gender division of labour and is situated at the intersection between productive (paid) and reproductive (unpaid) work (Elson 1999 in Barienthos et al. 2003).

This situation supports our assumption that generic intervention is acceptable but not empowering for women. Non-gender sensitive intervention does not lead to negative effects for women, it just maintains existing gender relations. It does not empower or disempower women. Empowerment can be defined as 'a process by which those who have been denied the ability to make strategic life choices acquire the ability to do so' (Kabeer 1999). In relation to women and value chains, empowerment is about changing gender relations in order to enhance women's ability to shape their lives. Clearly the actions we conducted did not enhance women's ability to shape their lives.

Positive impacts for women can be enhanced if actions specifically designed for women take place, such as skills training directed at women's activities (Fontana 2010). Training in furniture sanding, for instance, will impact upon women rather than men. Women will likely prefer halfday rather than full-day training schedules because of their household responsibilities. However, since women prefer market-based value chains and they are impacted upon more by moving-up actions, marketing training would provide a better impact for women if it was designed specifically for them. 
Social dialogue needs to be facilitated by promoting institutions that represent women's and men's interests equally (Fontana 2010). Such dialogue is not only about jobs and work - as it usually combines productive work with reproductive activities - but also about culture and religion. The imbalanced roles of women and men in the furniture industry only reflect a broader social context. It is necessary to look more deeply into social and religious contexts and find means for social transformation. Many engrained industries are influenced by cultures and religions, and the furniture industry in Jepara could be a frontier for social transformation.

\section{CONCLUSION}

Applying an action research model helps structure furniture upgrading into four phases: reflection, planning, action and monitoring. In the reflection phase, four types of value chain governance were identified: market-based, balanced network, directed network and hierarchical. To improve the role of small-scale furniture producers, four scenarios were developed: moving up, organising SME associations, collaborating down and developing green products. The scenarios were developed into action plans and implemented.

From the Jepara gender study we conclude that: (a) there was no verification of women workers' preference to be secure in value chain governance, in fact, they prefer a market-based relationship; (b) understanding women's position and preferences in a value chain helps in designing actions that have a greater impact upon them; and (c) non gender sensitive interventions stabilise and do not contribute to change in their gender relationships. We also found that women in Jepara are more cooperative in all-female groups. The strength of a value chain approach in the furniture industry is its aim to analyse all aspects of production and marketing through to consumption, but the totality of that analysis can only be achieved if gender is included. Specific actions designed for women are recommended to improve gender relations.

\section{ACKNOWLEDGEMENTS}

The study was conducted under the project of "Mahogany and teak furniture: action research to improve value chain efficiency and enhance livelihoods (FST/2007/119) 2008-2013" funded by Australian Centre for International Agricultural Research (ACIAR). Opinions expressed herein are solely of the authors and do not necessarily reflect the official views of their institutions.

\section{REFERENCES}

AGARWAL, B. 2010. Gender and Greeen Governance: The political economy of women's presence within and beyond community forestry. Oxford Univeristy Press, Oxford, UK. 488 p.
ASIAN DEVELOPMENT BANK (ADB). 2001. Special Evaluation Study on Gender and Development. $121 \mathrm{p}$.

BARIENTHOS, S. 2001. Gender, Flexibility and Global Value Chains. Institute of Development Studies. IDS Bulletin Vol 32, no. 3.

BARIENTHOS, S., DOLAN, C., TALLONTIRE, A. 2003. A gendered value chain approach to codes of conduct in African horticulture. World Development 31(9): 15111526.

EWASECHKO, A.C. 2005. Upgrading the Central Java Wood Furniture Industry: A Value-Chain Approach. ILO, Manila. 42 p.

FONTANA, M. with PACIELLO, C. 2010. Gender dimensions of agricultural and rural employment: Differentiated pathways out of poverty (Part I). FAO, Rome. 209 p.

FVC (Furniture Value Chains). 2011. Improving capacity of small-scale furniture producers to increase profit share: Institutions, certification and collective marketing. Furniture Value Chains News No. 4. CIFOR, Bogor.

HERR, M.L., HULTQUIST, I., ROGOVSKY, N. \& PYKE, F. 2006. A Guide for Value Chain Analysis and Upgrading. Rome, ILO.

KABEER, N. 1999. Resources, Agency, Achievements: reflections on the measurement of women's empowerment. Development and Change 30: 435-464.

KAPLINSKY, R. \& MORRIS, M. 2001. A Handbook for Value Chain Research, paper prepared for the IDRC. IDS. Available at: http://www.inti.gov.ar/cadenasdevalor/ manualparainvestigacion.pdf. 31 January 2010. 109 p.

MCINTOSH, P. 2010. Action Research and Reflective Practice: Creative and visual methods to facilitate reflection and learning. Routledge, New York. 189 p.

MILLER, T.F. \& AMATO, P.W. 2007. Evaluation of the Cambodia Strengthening Micro, Small and Medium Enterprise Program. USAID. Cambodia. 27 p.

MURADIAN, R. \& PELUPESSY, W. 2005. Governing the coffee chain: The role of voluntary regulatory Systems. World Developmen 33: 2029-2044.

NANSEREKO, S.C. 2010. A gender perspective to value chain analysis for wood-furniture industry upgrading: a case of Jepara, Central Java, Indonesia. Thesis for Department of Forest and Landscape Planning; Faculty of LIFE Sciences; Copenhagen University, Denmark unpublished.

PETER, G. 2006. Gender roles and relationships: implications for water management. Physics and Chemistry of the Earth 31(15-16): 723-730.

PURNOMO, H., GUIZOL, P. AND MUHTAMAN, D.R. 2009. Governing the teak furniture business: A global value chain system dynamic modelling approach. Environmental Modelling and Software Journal 24, pp. 1391-1401.

PURNOMO, H., MELATI, IRAWATI, R.H. 2009. Furniture and People: A photo journey from market to forest. CIFOR, Bogor. $119 \mathrm{p}$.

RIISGAARD, L., ESCOBAR FIBLA, A.M.; PONTE, S. 2010. Gender and value chain development: Evaluation 
study. The Danish Institute for International Studies, Copenhagen, Denmark. Available at: http://www.oecd. org/dataoecd/8/17/45670567.pdf (10 November 2010).

RODA, J.M., CADÈNE, P., GUIZOL, P., SANTOSO, L., FAUZAN, A.U. 2007. Atlas of Wooded Furniture Industry in Jepara, Indonesia. French Agricultural Research Centre for International Development (CIRAD), Montepellier. $52 \mathrm{p}$.
GAMMAGE, S. 2009. Gender and Pro-Poor Value Chain Analysis: Insights from the GATE project methodology and case studies. USAID. Washington D.C.

SCHMITZ, H. 2005. Value Chain Analysis for Policy Makers and Practitioners. ILO, Geneva. 73 p.

SELENER, D. 1997. Participatory Action Research and Social Change. Cornell Participatory Action Research Network, Cornell University, New York. 358 p. 